\title{
Parasites and cephalopod fisheries uncertainty: towards a waterfall understanding
}

\author{
S. Pascual · A. González • A. Guerra
}

Published online: 5 June 2007

(C) Springer Science+Business Media B.V. 2007

\section{Erratum to: Rev Fish Biol Fisheries DOI 10.1007/s11160-006-9021-y}

This erratum is being published as a result of misspelt co-author's name.

A. Gonzáez is now to be read as A. González.

The online version of the original article can be found under doi:10.1007/s11160-006-9021-y

S. Pascual $(\bowtie) \cdot$ A. González · A. Guerra ECOBIOMAR, Instituto de Investigaciones Marinas (CSIC), Eduardo Cabello 6, 36208 Vigo, Spain e-mail: spascual@iim.csis.es 